\title{
A Formação do Profissional Médico e a Necessidade do Desenvolvimento de uma Competência Valorativa
}

\author{
Ruthes, Vanessa Roberta Massambani \\ Pontifícia Universidade Católica do Paraná — vanessa_ruthes@yahoo.com.br
}

INTRODUÇÃO a medicina, como todas as ciências, é mais que um saber puro, é uma construção histórica da civilização. como afirma FEUERWERKER, os modelos sanitários, e em particular a prática e a educação médica em vigor em uma dada sociedade e em um dado momento, estão baseados na concepção predominante gerando modelos do processo saúde-doença. Este que é devidamente influenciado pelas relações socioeconômicas, políticas e ideológicas "relacionadas com o saber teórico e prático sobre saúde e doença, sobre organização, administração dos serviços e a clientela dos serviços de saúde" (FEUERWERNER. 2002. p. 3.). para GRACIA, estes modelos são imprescindíveis para compreendermos não só a educação formal dos Médicos, mas também a própria forma como os mesmos praticam a medicina. para ele, nos diferentes tempos da civilização e em seus respectivos períodos de mudança é que se descobrem as novas possibilidades (GRACIA. 2010. p. 37). Atualmente a medicina é vista como bem de consumo. o relacionamento com a paciente não é necessariamente e somente intervencionista é educativo, participativo e gerador de autonomia. Sendo que o modelo tradicional de formação Médica já não atende as necessidades hordienas, a formação técnica tem que estar transversalizada por uma educação valorativa. como afirma GRACIA: "Humanizar a medicina é nela introduzir o mundo dos valores, leva-los em conta; é, em última instância, superar afinal o velho preconceito positivista" (2010. p. 110). OBJETIVOS Refletir acerca do processo formativo do profissional médico e as exigências atuais para 0 exercício humanista da profissão. MÉTODOS Tendo como fundamento a definição do perfil do formando em Medicina delineado nas Diretrizes Curriculares Nacionais: "Médico, com formação generalista, humanista, crítica e reflexiva", utilizamos a metodologia qualitativa e quantitativa. Procurou-se, com bases de dados obtidos em Ouvidorias de Hospitais confrontar o ideal (expresso nas Diretrizes) e o real (dados das Ouvidorias). RESULTADOS na análise dos dados percebeu-se de forma efetiva que a educação de base (Graduação) não oferece a educação valorativa necessária para que os profissionais médicos executem sua profissão tendo como princípio a humanização. CONCLUSÕES Podemos afirmar que duas são as conclusões básicas: a primeira que os Cursos de Graduação em medicina precisam repensar seus Currículos e as Propostas pedagógicas; mas também é necessário levar os profissionais já formados e atuantes na profissão a um processo de desenvolvimento de uma competência valorativa. Isto seria possível por meio de Cursos, de uma proposta de formação dos Programas de Residência Médica. o fato é que tal necessidade é necessária e em alguns casos urgente.

Ruthes, Vanessa Roberta Massambani. A Formação do Profissional Médico e a Necessidade do Desenvolvimento de uma Competência Valorativa. In: Anais do Congresso Internacional de Humanidades \& Humanização em Saúde [= Blucher Medical Proceedings, num.2, vol.1]. São Paulo: Editora Blucher, 2014. ISSN 2357-7282

DOI 10.5151/medpro-cihhs-10435 